\title{
Intensive volcanic eruptions recorded in black shales within the Xiamaling Formation in the North China Craton
}

SHUAN-HONG ZHANG ${ }^{1}$, SANDRA KAMO ${ }^{2}$, RICHARD E. ERNST $^{3,4}$, JUNLING PEI ${ }^{5}$, GUOHUI HU ${ }^{5}$ AND QI-QI ZHANG $^{5}$

${ }^{1}$ Institute of Geomechanics, Chinese Academy of Geological Sciences

${ }^{2}$ Department of Earth Sciences, University of Toronto

${ }^{3}$ Carleton University

${ }^{4}$ Tomsk State University

${ }^{5}$ Institute of Geomechanics, Chinese Academy of Geological

Sciences, MNR Key Laboratory of Paleomagnetism and

Tectonic Reconstruction

Presenting Author: tozhangshuanhong@163.com

The Xiamaling Formation in the Yanliao rift zone in the northern North China Craton (NCC) consists of shale and mudstone and was deposited in a tectonically quiet marine basin. Black shales are very common at the middle part of the Xiamaling Formation and are 100-300 m thick. Tuff (or Kbentonite beds) with TIMS and SHRIMP zircon U-Pb ages of $1384 \pm 1 \mathrm{Ma}$ to $1366 \pm 9 \mathrm{Ma}$ with a peak age of $1384 \mathrm{Ma}$ and a weighted mean age of $1383 \pm 2$ Ma have been identified from the black shales within the middle part of the Xiamaling Formation ${ }^{[1-}$ 3]. The Xiamaling Formation in the NCC and the Velkerri Formation in North Australian Craton were most likely deposited in the same basin of Nuna/Columbia supercontinent ${ }^{[4-5]}$.

Our investigations show that the frequency and thickness of tuff beds are increasing from lower part of black shales to the middle part, and than disappear quickly. Specially, four thick tuff layers with thickness of $3-5 \mathrm{~cm}$ have been identified from middle part of the Xiamaling black shales (Figure 1). These four thick tuff beds are distributed over a large area that is $c a .400 \mathrm{~km}$ long from Lingyuan in east to Xiahuayuan in west and represent the most extremely intensive explosive volcanic eruptions during deposition of the black shales. Our new zircon CA-ID-TIMS U$\mathrm{Pb}$ dating of tuffs from Lingyuan and Chengde obtained two weighted mean ${ }^{206} \mathrm{~Pb} /{ }^{238} \mathrm{U}$ ages of $1382.1 \pm 1.3$ Ma and 1380.0 $\pm 1.1 \mathrm{Ma}$, respectively, indicating extremely intensive volcanic eruptions at 1382-1380 Ma. Large areal extent of four thick tuff layers in Xiamaling black shales in the NCC most likely recorded some extremely intensive explosive volcanic eruptions during a short period in Earth's history.

This research was financially supported by the NNSFC (41920104004, 41725011).

[1] Gao et al. (2007) Geol Bull China 26, 249-255. [2] Su et al. (2008) Gondwana Res 14, 543-553. [3] Zhang et al. (2015) PNAS 112, 1406-1413. [4] Zhang et al. (2018) Geology 46, 963966. [5] Mitchell et al. (2021) Geology 49, 25-29.
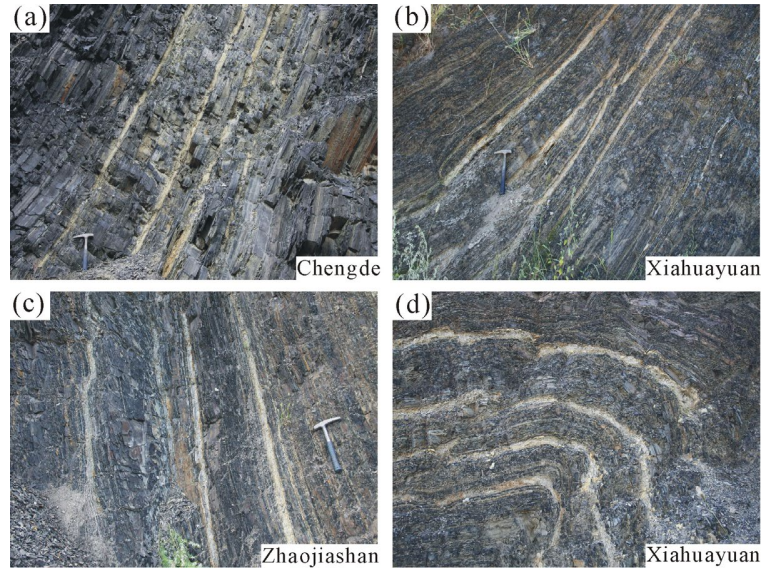